\title{
Parasitism in bivalves from an Arctic ecosystem
}

\author{
G. Høpner Petersen \\ Zoological Museum University of Copenhagen, Universitetsparken 15, \\ DK-2100 Copenhagen 0, Denmark
}

\begin{abstract}
In arctic ecosystems parasitism seems less conspicuous than in more diverse tropical ecosystems. However, several host-parasite relations may be a burden in Arctic ecosystems and modify energy-flow patterns. Four different localities of the shallow shelf off Godhavn, West Greenland, were studied with regard to biomass, production and life cycles of selected bivalve and polychaete species. The following important parasite-bivalve associations were found: the athecate hydroid Monobrachium parasitum on Macoma calcarea; the digenetic trematode Gymnophallus somateriae in Hiatella byssifera; an unidentified species of turbellarian in Hiatella byssifera; and the nemertean Malacobdella grossa in Mya truncata. In the bivalves Mytilus edulis, Serripes groenlandicus and Cardium ciliatum only few parasites were detected. Parasitism seems to follow the general trend observed in Arctic ecosystems which exhibit low species diversities and high numbers of individuals.
\end{abstract}

\section{INTRODUCTION}

Investigations concerning the production of bivalves in Disko Bugt, West Greenland (Petersen, 1978) included some parasitological observations. Complemented by results on polychaete production (Curtis, 1977), they were used to outline the energy flow in marine ecosystems (Petersen \& Curtis, 1980). Bivalves and polychaetes are probably the most important primary consumers in the benthic food pool, which occurs in the sediment just below and the water layer just above the bottom. Even though reasonable estimates of the total energy flow from incident solar energy to fish yield were obtained, many problems remain unsolved. Thus the food webs are not sufficiently known and recycling of energy within the benthic food pool through predation, parasitism, cannibalism, microbial decomposition etc. can bias the estimates of total production within each compartment of the energy flow sheet (Petersen, 1984).

Even if parasitism in a subarctic ecosystem seems less conspicuous than in warmer seas it should not be ignored in energy-flow studies. In Disko Bugt and West Greenland, parasites have been studied by Baer (1956), Bresciani \& Lützen (1974), Brinkmann (1975), Just (1983), and Køie (1979, 1980). The present study concentrates on four hostparasite relationships investigated in this area.

\section{MATERIALS AND METHODS}

In material collected for the study of life histories and production of benthic species at 4 localities (Figs 1 and 2), about 15,000 specimens from 24 species of bivalves were examined. Gonads and stomachs were dissected in the following species: Mytilus edulis, 


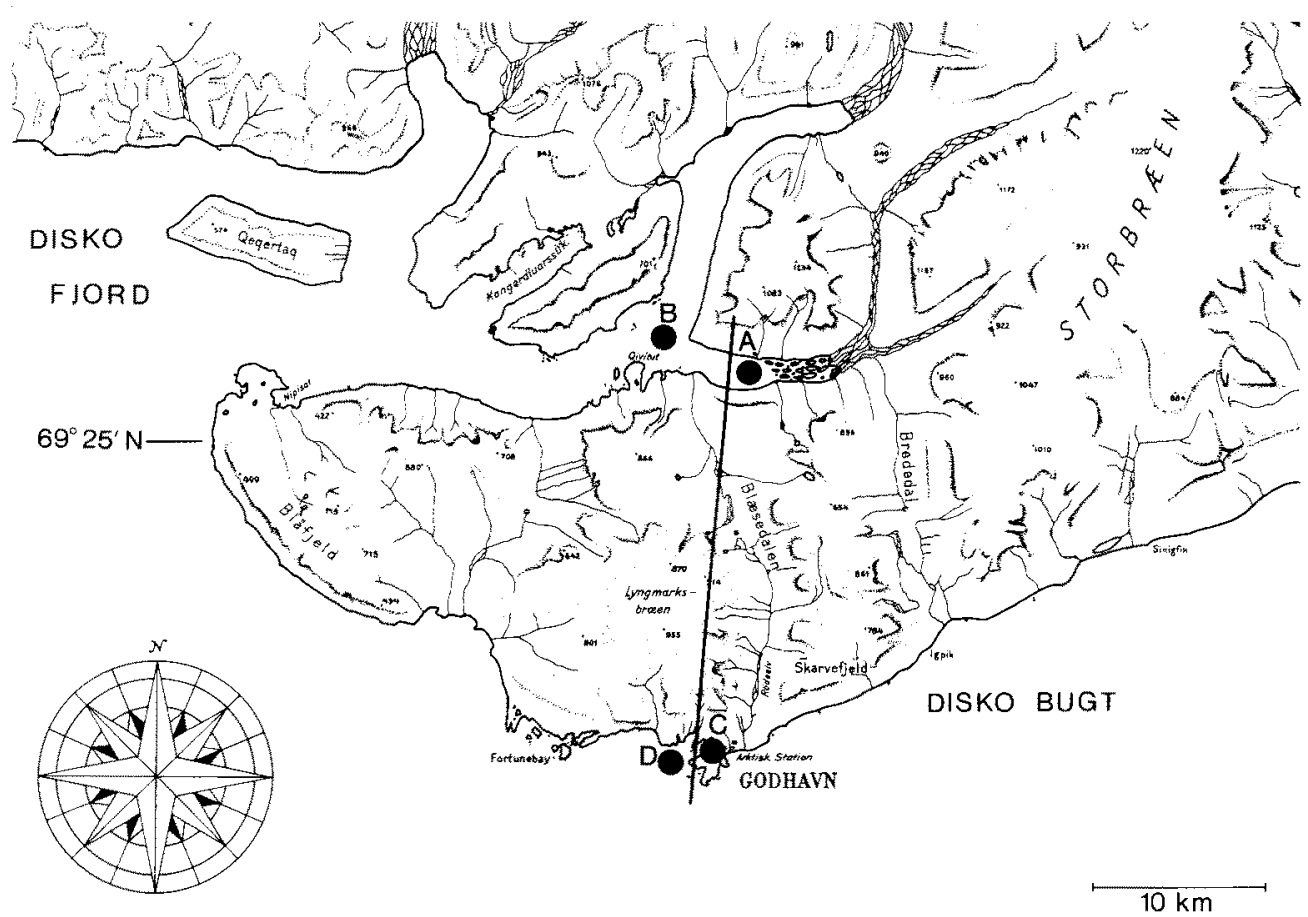

Fig. 1. Map of study area. Disko Fjord (West Greenland) is a sheltered area with a maximum depth of ca $200 \mathrm{~m}$ at the mouth. The two localities studied are at 3-18 m (A) and 80-107 m (B). Disko Bugt is an exposed, oceanic area with a maximum depth of about $800 \mathrm{~m}$. The investigated localities are at $3-13 \mathrm{~m}(\mathrm{C})$ and $26-47 \mathrm{~m}$ (D). The transect of the area shown in Fig. 2 is indicated by a heavy line. Phytoplankton production in Disko Fjord $\left(300 \mathrm{kcal} / \mathrm{m}^{2} / \mathrm{yr}^{2}\right)$ and Disko Bugt $\left(900 \mathrm{kcal} / \mathrm{m}^{2} / \mathrm{yr}\right) \mathrm{are}$ indicated

Serripes groenlandica, Cardium ciliatum, Macoma calcarea, Hiatella byssifera and Mya truncata. Parasites were not found in Serripes groenlandica and Cardium ciliatum. Mytilus edulis showed minor attacks of cercarians. The remaining three species contained the parasites described below.

\section{RESULTS}

\section{Macoma calcarea - Monobrachium parasitum}

Colonies of the hydroid Monobrachium parasitum were found on $30-50 \%$ of Macoma calcarea individuals, where they are located on the posterior end of the shell. Monobrachium parasitum was found only on this species. The hydroid thrives best on exposed localities in shallow depth, where the growth of the host is also optimal and the highest production is observed. Each individual of the infested Macoma calcarea bears colonies of the hydroid with an average 10-30 hydrants and 5-10 gonophores, with the highest numbers during summer. The degree of infestation at the other localities is high, but the hydroid is less well developed, the growth of Macoma calcarea is reduced, and the total production is smaller. The parasite, which lives for several years, is a severe 


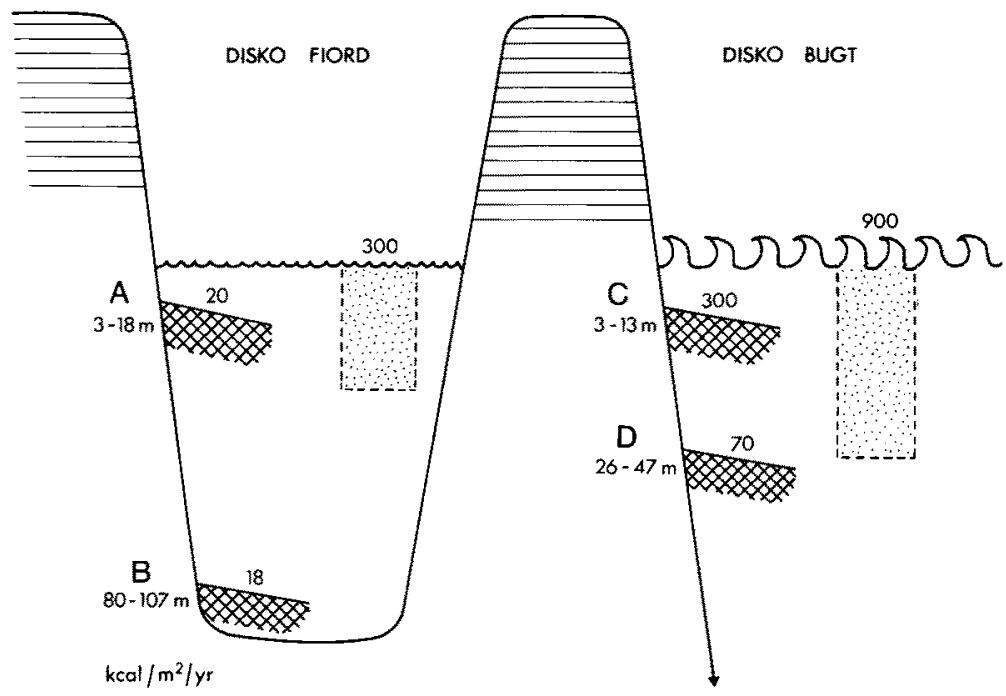

Fig. 2. Transect through the investigated area shown in Fig. 1. The estimated phytoplankton production is given in figures above the stippled column, whose depth also indicate the depth of the photic layer. The estimated total benthic production is given in figures above the cross-hatched areas whose position indicate the four different localities. Waves indicate sheltered and exposed shores. The information presented in Figs 1 and 2 has been compiled from Andersen (1981), Curtis (1977), Petersen (1964, 1977) and Petersen \& Curtis (1980)

burden for an infested Macoma calcarea. Therefore, growth and maximum size of the parasitized bivalves are reduced; their gonads are never fully developed, and their soft parts relatively light. Approximately $50 \%$ of the food consumed by infested $M$. calcarea individuals is converted into hydroid tissue instead of Macoma tissue. However, it is not easy to interpret its influence on the total production, because the hydroid may protect Macoma against predation from eiders, fish and other animals.

\section{Hiatella byssifera - Gymnophallus somateriae}

All Hiatella byssifera individuals examined, except for the 0-group, were heavily infested by the metacercarian Gymnophallus somateriae. Some of the bivalves studied contained more than 100 living parasites. The life cycle of the parasite in the bivalve is probably as follows: In spring and early summer the new population of small, ca $0.1 \mathrm{~mm}$ long, metacercarians pass the mantle cavity, penetrate the mantle and move into the extrapallial fluid. Here they grow to a size of ca $0.4 \mathrm{~mm}$ in the following season; probably they die in the third season, and eventually become encrusted in the shell (or vice versa). All stages of the dead metacercarians can be seen in the shell, from recently encrusted specimens to brown spots deep in the shell. The inside of the shell may exhibit serious calcareous deformations, which may be harmful to the host. The deformations cannot be seen from the outside. Hiatella byssifera is eaten by two species of eiders: Somateria mollissima, a common breeding bird, and huge flocks of molting males of Somateria spectabilis. The large biomass and production of Hiatella byssifera together with heavy predation of eiders provide excellent support for Gymnophallus somateriae 
in this area. G. somateriae damages the shell, but not the gonad development. As infection rate is $100 \%$, it is impossible to study the effects of infestation on growth.

\section{Hiatella byssifera - turbellarian sp.}

In the mantle cavity, mainly in the plications of the retracted siphons, some pink turbellarians with black eyes and a length of 0.2 to $0.6 \mathrm{~mm}$ are found.

They have not been identified at the genus or species level; probably, they are harmless commensals. They may be intermediate stages of, for example, the parasitic Fecampiidae. These turbellarians, which are most common during summer, have not been found in other material or in the free-living state.

\section{Mya truncata - Malacobdella grossa}

Malacobdella grossa is mainly found in slow-growing populations of Mya truncata in sheltered shallow localities, which are heavily influenced by brackish muddy meltwater during summer and sea-ice cover during the other 7 months of the year. Primary production is low. In each of the infested Mya truncata, only one Malacobdella grossa was found. In the apparently environmentally stressed population, infestation rates range up to $100 \%$ in older bivalves, and Malacobdella can weigh up to $12 \%$ of the softbody weight of the bivalve. The marks and scars seen on body and gills of Mya truncata indicate that Malacobdella grossa constitutes a burden for the host. The fast-growing Mya truncata populations harbour only very few Malacobdella grossa individuals. Thus, this parasite is not important for production estimates.

Table 1. Parasitism related to exposure and water depth ++++ very significant; ++ significant; + present; $O$ absent

\begin{tabular}{|c|c|c|c|}
\hline \multirow[t]{2}{*}{ Host-parasite relationship } & \multirow[t]{2}{*}{ Depth } & \multicolumn{2}{|c|}{ Area } \\
\hline & & sheltered & exposed \\
\hline Macoma calcarea - Monobrachium parasiticum & $\begin{array}{l}\text { shallow } \\
\text { deep }\end{array}$ & $\begin{array}{l}+t \\
+t\end{array}$ & $\begin{array}{c}++t \\
+\end{array}$ \\
\hline Hiatella byssifera - Gymnophallus somateriae & $\begin{array}{l}\text { shallow } \\
\text { deep }\end{array}$ & $\begin{array}{l}0 \\
0\end{array}$ & $\begin{array}{c}+++ \\
0\end{array}$ \\
\hline Hiatella byssifera - turbellarian & $\begin{array}{l}\text { shallow } \\
\text { deep }\end{array}$ & $\begin{array}{l}0 \\
0\end{array}$ & $\begin{array}{c}+++ \\
0\end{array}$ \\
\hline Mya truncata - Malocobdella grossa & $\begin{array}{l}\text { shallow } \\
\text { deep }\end{array}$ & $\begin{array}{c}++t \\
0\end{array}$ & $\begin{array}{l}+ \\
+\end{array}$ \\
\hline
\end{tabular}

\section{DISCUSSION}

Most studies on host-parasite relationships in marine environments are concerned with selected taxonomic groups of parasite or host. This study, however, is based on a representative sample taken at random from a subarctic benthic bivalve fauna. Hence, it provides some insight into ecologically important host-parasite associations (Table 1). Several types are present, ranging from parasites that benefit from high production and 
high predation (Gymnophallus somateriae), to parasites which both take a high toll of its host but also may protect it (Monobrachium parasitum), to parasites which obviously take advantage of a weakened population (Malacobdella grossa), and to harmless commensals. Although I have not made a detailed study of parasitism in bivalves from other areas (Petersen, 1968, 1977), parasites from Arctic environments seem to follow the general trend that in the Arctic the number of species decreases while the number of individuals increases compared to more temperate areas. Hence, certain types of parasitism can be studied more easily in the Arctic, although these are not necessarily the same type as those known from warmer seas, because benthic energy flow dominates in the Arctic, while pelagic energy flow dominates in tropical ecosystems. A food chain such as host-ectoparasite-cleaner is common in tropical ecosystems, but rare or absent in Arctic ecosystems.

The influence of parasitism on the energy flow was supposed to be negligible, even if it was a burden for the hosts. However, the results of this study show that parasitism can complicate important energy flow patterns. Nevertheless, further studies are necessary to evaluate its quantitative importance.

\section{LITERATURE CITED}

Andersen, Ole Norden, 1981. The annual cycle of phytoplankton primary production in the Disko Bugt area, West Greenland. - Meddr Grønland (Bioscience) 6, 1-65.

Baer, Jean, G., 1956. Parasitic Helminths collected in West Greenland. - Meddr Grønland 124 (10), $1-55$.

Bresciani, I. \& Lützen, J., 1974. On the biology and development of Aphanodomus Wilson (Xenocoelomidae), a parasitic copepod of the polychaete Thelepus cincinnatus. - Vidensk. Meddr dansk naturh. Foren. 137, 25-63.

Brinkmann, A., 1975. Trematodes from Greenland. - Meddr Grenland 205 (2), 1-88.

Curtis, Mark A., 1977. Life cycles and population dynamics of marine benthic polychaetes from the Disko Bay area of West Greenland. - Ophelia 16, 9-58.

Just, J., 1983. Anonyx affinis (Crust., Amphipoda: Lysianassidae), commensal in the bivalve Musculus laevigatus, with notes on Metopa glacialis (Amphipoda: Stenothoidae). - Astarte 12, 69-74.

Køie, M., 1979. On the morphology and life-history of Monascus [= Haplocladus] filiformis (Rudolphi, 1819) Loos 1907 and Steringophorus furciger (Olsson, 1868) Odhner, 1905 (Trematoda, Fellodistomidae). - Ophelia 18, 113-132.

Køie, M., 1980. On the morphology and life-history of Steringotrema pagelli (Van Beneden, 1871) Odhner, 1911 and Fellodistomum fellis (Olsson, 1868) Nicoll, 1909 [Syn. S. ovacutum (Lebour, 1908) Yamaguti, 1953] (Trematoda, Fellodistomidae). - Ophelia 19, 215-236.

Petersen, G. Hepner, 1964. The hydrography, primary production, bathymetry and "Tagsaq" of Disko Bugt, West Greenland. - Meddr Grønland 159 (10), 1-45.

Petersen, G. Høpner, 1968. Marine lamellibranchiata. - Zoology Faroes 3, 1 (55), 1-80.

Petersen, G. Høpner, 1977. The density, biomass and origin of the bivalves of the central North Sea. - Meddr Danm. Fisk.-og Havunders. 7, 221-273.

Petersen, G. Høpner, 1978. Life cycles and population dynamics of marine benthic bivalves from the Disko Bugt area of West Greenland, - Ophelia 17, 95-120.

Petersen, G. Hepner, 1984. Energy flow in comparable aquatic ecosystems from different climatic zones. - Rapp. P.-v. Réun. Cons. int. Explor. Mer 183, 119-125.

Petersen, G. Høpner \& Curtis, Mark A., 1980. Differences in energy flow through major components of subarctic, temperate and tropical marine shelf ecosystems. - Dana 1, 53-64. 